\title{
Open-ocean convection and polynya formation in a large-scale ice-ocean model
}

\author{
By HUGUES GOOSSE* and THIERRY FICHEFET, Institut d'Astronomie et de Géophysique Georges \\ Lemaître, Université Catholique de Louvain, Louvain-la-Neuve, Belgium
}

(Manuscript received 22 February 1999; in final form 13 June 2000)

\begin{abstract}
The physical processes responsible for the formation in a large-scale ice-ocean model of an offshore polynya near the Greenwich meridian in the Southern Ocean are analysed. In this area, the brine release during ice formation in autumn is sufficient to destabilise the water column and trigger convection. This incorporates relatively warm water into the surface layer which, in a first step, slows down ice formation. In a second step, it gives rise to ice melting until the total disappearance of the ice at the end of September. Two elements are crucial for the polynya opening. The first one is a strong ice-transport divergence in fall induced by southeasterly winds, which enhances the amount of local ice formation and thus of brine release. The second is an inflow of relatively warm water at depth originating from the Antarctic Circumpolar Current, that sustains the intense vertical heat flux in the ocean during convection. The simulated polynya occurs in a region where such features have been frequently observed. Nevertheless, the model polynya is too wide and persistent. In addition, it develops each year, contrary to observations. The use of a climatological forcing with no interannual variability is the major cause of these deficiencies, the simulated too low density in the deep Southern Ocean and the coarse resolution of the model playing also a role. A passive tracer released in the polynya area indicates that the water mass produced there contributes significantly to the renewal of deep water in the Weddell Gyre and that it is a major component of the Antarctic Bottom Water (AABW) inflow into the model Atlantic.
\end{abstract}

\section{Introduction}

Since the beginning of passive-microwave remote sensing of sea ice, polynyas (i.e., large icefree areas within the sea-ice pack) have been regularly observed in the Southern Ocean (Carsey, 1980; Zwally et al., 1985). These features are kinds of gate inside the insulating ice blanket in which the exchanges of heat, moisture, and gases between ocean and atmosphere are much stronger than in

* Corresponding author address: Institut d'Astronomie et de Géophysique G. Lemaître (ASTR), Université Catholique de Louvain, 2 Chemin du Cyclotron, B-1348 Louvain-la-Neuve, Belgium.

e-mail: hgs@astr.ucl.ac.be ice-covered regions. Their presence thus significantly affects the local weather and oceanographic conditions as well as the large-scale oceanic and atmospheric circulations and the uptake of atmospheric gases by the ocean (Martinson et al., 1981; Gordon, 1991; Bromwich et al., 1998).

The polynya opening can result from two complementary mechanisms (Comiso and Gordon, 1987; Smith et al., 1990). First, the ice can be continually exported out of the polynya area. As the strong atmospheric heat loss at the oceanatmosphere interface in the polynya is compensated for by the latent-heat release during ice freezing, these polynyas are referred to as latentheat polynyas. The atmospheric heat loss can also be balanced by the oceanic sensible-heat flux, 
which melts the ice or forbids its formation. The polynyas in which this mechanism is dominant are referred to as sensible-heat polynyas.

Offshore polynyas such as the Weddell polynya, which covered about $350,000 \mathrm{~km}^{2}$ during the winters of 1974, 1975, and 1976, or the smaller-scale recurring polynyas observed over the Cosmonaut Sea $\left(\sim 51^{\circ} \mathrm{E}, 62^{\circ} \mathrm{S}\right)$ and Maud Rise $\left(\sim 2^{\circ} \mathrm{E}, 64^{\circ} \mathrm{S}\right)$ are generally considered to be sensible-heat polynyas (Martinson et al., 1981; Motoi et al., 1987; Comiso and Gordon, 1987; Smith et al., 1990). For the particular case of the Cosmonaut Sea, Comiso and Gordon (1996) suggest that the oceanic heat flux results from a strong oceanic upwelling enhanced by local topography which injects relatively warm water in the surface layer. Nevertheless, the intense vertical heat transfer in the ocean responsible for the formation of sensibleheat polynyas is generally attributed to the oceanic deep convection.

There is some evidence of such a deep convection in the Weddell Sea. For instance, Gordon (1978) found a 4000-m-deep chimney in 1977 at $7^{\circ} \mathrm{W}, 67^{\circ} \mathrm{S}$ probably linked with the Weddell polynya that occurred the preceding year. The cooling and freshening of the water over a great depth $(>2000 \mathrm{~m})$ near the Greenwich meridian between pre- and post-polynya years (Gordon, 1982) is also consistent with the hypothesis of strong convection in the Weddell polynya. The effects of the smaller polynyas on the water column are more difficult to detect. Some convective features have been noticed in various regions (Bersh, 1988; Muench, 1991), but their association with a particular polynya detected from satellite observations is not obvious.

In the major part of the Southern Ocean, the stability of the water column below sea ice is due to the low salinity of the surface layer compared to the water below. The temperature increases with depth, which has a destabilising effect, but this is generally counteracted by the salinity difference. Gordon (1991) refers to this type of stratification as the saline mode. Even though the stratification is weak, it can be maintained thanks to strong stabilising feedbacks (Martinson, 1990). This stratification has to be destroyed to allow deep convection to happen and to generate an offshore polynya. In these polynyas, warm water is incorporated in the surface layer because of the strong vertical exchanges induced by convection, the wind stirring also contributing to the mixing, particularly during storms. This water is rapidly cooled by direct contact with the polar atmosphere, becomes denser, and sinks again, thus intensifying the convection. Gordon (1991) has termed this state of the ocean in which the stability is low and convection is driven by temperature instability the thermal mode.

In the present paper, we investigate the causes and consequences of offshore polynya formation and open-ocean convection in a global, coarseresolution ice-ocean model. As coarse-resolution models are used in simulations of the World Ocean's circulation and in climate studies, it is helpful to understand their behaviour regarding these important processes. The simulations performed with the model could also bring useful information on the mechanisms that lead to the polynya opening as well as on the impacts of polynyas on the ice-ocean system.

After a brief description of the model and of its performance in the Southern Ocean (Section 2), the development of a polynya near the Greenwich meridian is analysed in detail in Section 3. In Section 4 , the local conditions that favour the opening of this polynya are identified by means of a series of sensitivity experiments. The comparison with observations made in Section 5 reveals that the model overestimates the polynya duration and extent. This overestimation of the ice-free areas in the high latitude of the Southern Ocean is a classical problem of current large-scale iceocean models (Legutke et al., 1997; Goosse et al., 1997; Stössel et al., 1998), as well as of some higher resolution models (Van Ypersele, 1989; Häkkinen, 1995), which is associated with a too frequent and widespread open-ocean convection in those models. The causes of this unrealistic behaviour are investigated in Section 5. Finally, the impact of the polynya formation on the ventilation of the model Southern Ocean and on the characteristics of the deep-water masses are discussed in Section 6. In this context, a passive tracer is released at the surface in the polynya area and its evolution in the ocean is followed. Concluding remarks are then presented in Section 7.

\section{Model description and performance}

Apart from the inculsion of a more sophisticated representation of the oceanic vertical mixing 
(Goosse et al., 1999) and of a parameterization of density-driven downslope flows (Campin and Goosse, 1999), the ice-ocean model used in this study (called CLIO for Coupled Large-scale IceOcean) is identical to that of Goosse et al. (1997). It is made up of a primitive-equation, free-surface ocean general circulation model coupled to a thermodynamic-dynamic sea-ice model with viscous-plastic rheology. The new parameterization of vertical mixing is based on a simplified version of Mellor and Yamada's (1982) level-2.5 turbulence-closure scheme with the minimum values for vertical diffusivity and viscosity following the vertical profile proposed by Bryan and Lewis (1979). Whenever the vertical density profile is unstable, the vertical diffusivity is enhanced to $10 \mathrm{~m}^{2} \mathrm{~s}^{-1}$. The horizontal eddy diffusivity and viscosity are set equal to $150 \mathrm{~m}^{2} \mathrm{~s}^{-1}$ and $10^{5} \mathrm{~m}^{2} \mathrm{~s}^{-1}$, respectively. The model domain is global. The horizontal resolution is of $3^{\circ} \times 3^{\circ}$, and there are 20 unequally spaced vertical levels in the ocean.

The model is dynamically driven by the climatological monthly wind stresses of Hellerman and Rosenstein (1983) between $15^{\circ} \mathrm{S}$ and $15^{\circ} \mathrm{N}$ and of Trenberth et al. (1989) out of this latitude band. The surface fluxes of heat are determined from atmospheric data by using classical bulk formulas. Input fields consist of monthly climatological surface air temperatures (Taljaard et al., 1969; Crutcher and Meserve, 1970), cloud fractions (Berliand and Strokina, 1980), air relative humidities (Trenberth et al., 1989), and surface winds (same sources as for wind stresses). Evaporation/ sublimation is derived from the turbulent flux of latent heat. Precipitation and freshwater inflow from the largest rivers are prescribed according to the monthly climatologies of Xie and Arkin (1996) and Grabs et al. (1996), respectively. For smaller rivers, the annual runoff values of Baumgartner and Reichel (1975) are utilised. In addition, a relaxation towards observed annual mean salinities (Levitus, 1982) is applied globally in the 10 -m-thick surface grid box with a time constant of 60 days. This correction is introduced in order to prevent any salinity drift caused by inaccuracies in the precipitation and runoff data and in the evaporation computed by the model.

The spin-up procedure was the following. The model was first integrated for 20 years in robust diagnostic mode (i.e., with restoring of salinity and temperature to Levitus' observations at all depths) from a state of rest with no ice and horizontally uniform profiles of potential temperature and salinity. The relaxation was then suppressed, except in the uppermost grid box for salinity (see above), and the integration was pursued for 1000 years. The results discussed below are averages over the last 10 years of this experiment. Actually, this 10-year average is not very different from a particular year since the experiment displays only a very weak interannual variability.

The March and September ice concentrations computed by the model in the Southern Ocean are displayed in Fig. 1. The model results are in reasonable agreement with observations even if the ice extent is slightly overestimated in the eastern Weddell Sea during summer. In addition, in September, the ice extent is somewhat underestimated in the western Weddell Sea and overestimated in the Bellingshausen and Amundsen Seas. The modelled winter ice thicknesses in the Southern Ocean are within the range of observational estimates (Budd, 1991), although probably on the high side, with an average value of about $1 \mathrm{~m}$.

In September, two open-ocean polynyas are visible (Fig. 1b): one near the $90^{\circ} \mathrm{E}$ meridian and the other close to the Greenwich meridian. The present study turns on the latter polynya only (we refer the reader to Goosse (1997) for a discussion of the processes responsible for the formation of the first one). The diagnostics are performed over the region going from $9^{\circ} \mathrm{E}$ to $15^{\circ} \mathrm{E}$ and from $66^{\circ} \mathrm{S}$ to $69^{\circ} \mathrm{S}$ (two grid points), which corresponds to the zone where the polynya appears first in the model. Even though the polynya covers a wider area after the initial stage, it can only be considered as marginally resolved because of the coarse resolution of the model. This problem is discussed in Section 5.

\section{Polynya opening in the model}

In January and February, the sea-surface salinity is rather low in the polynya area and the upper ocean is strongly stratified (Fig. 2a,b) because of the local melting of the ice imported from surrounding regions (Fig. 3b). At the beginning of March, the melting weakens and part of the ice 


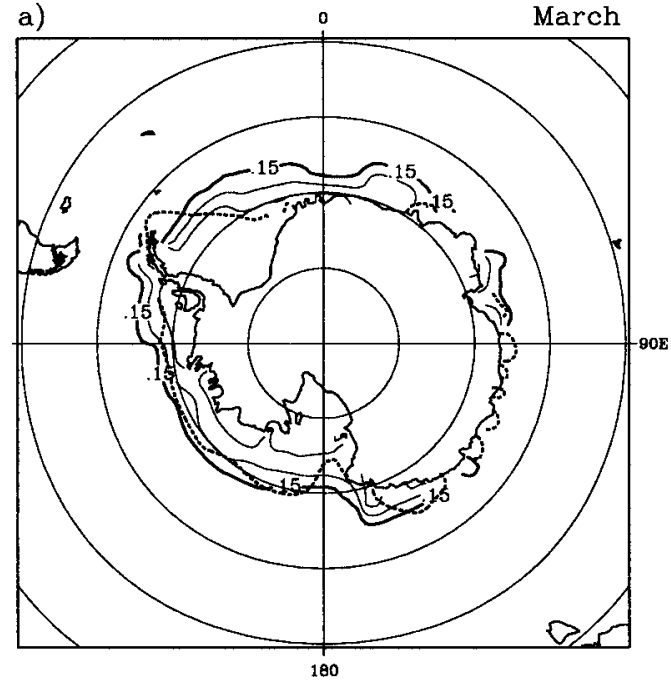

b)

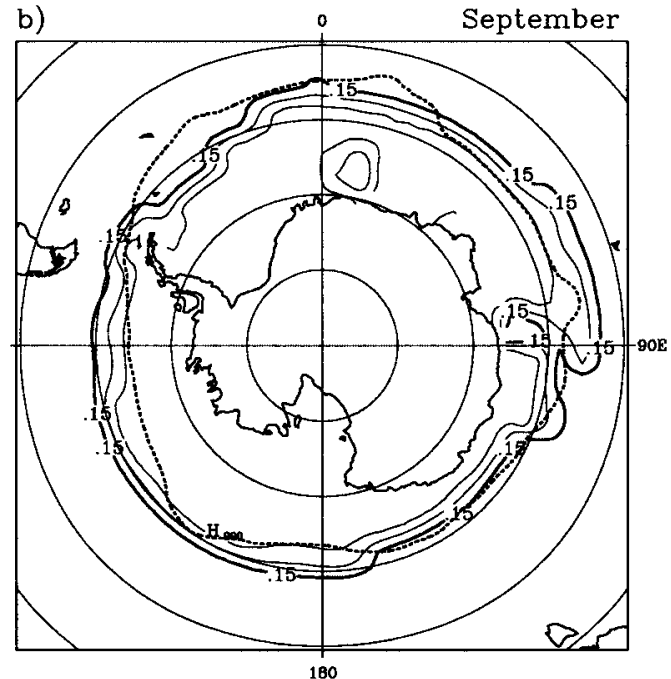

Fig. 1. Ice concentrations simulated by the model in the Southern Ocean for (a) March and (b) September Selected contours are $0.15,0.50$, and 0.85 . Also shown is the 0.15 ice concentration contour as derived from the scanning multichannel microwave radiometer (SMMR) data (Gloersen et al., 1992; thick dashed line).

imported can be maintained in the polynya sector (Fig. 3a) (this is more than one month earlier than in the observations). At the end of March, ice starts forming locally (Fig. 3b). The brine release induces an increase in surface salinity and a destabilisation of the water column (Fig. 4). The oceanic cooling during this time period plays a role in this destabilisation, but is less important. As a consequence, the mixed layer deepens (Fig. 2c), slowly in April, but faster as the cold season progresses. This generates a strong heat flux at the ice bottom which slows down ice formation (Fig. 3b), in agreement with the observations of Wadhams et al. (1987) and with the model results of Martinson (1990). After day 120 (beginning of May), the ice formation is no more able to compensate for the strong ice-transport divergence that takes place at this time (Fig. 3b). Therefore, the mean ice thickness decreases, initiating the polynya opening.

The oceanic heat flux becomes large enough after day 160 to induce local ice melting (Fig. 3b). The freshwater flux associated with this melting tends to stabilise the water column (see Martinson, 1990 for a comprehensive description of this stabilising feedback). But, the net buoyancy flux is still destabilising because of the strong cooling (Fig. 4), and therefore, the mixed-layer deepening continues (Fig. 2c). This stage in the evolution of the ice-ocean system is very close to the "freeze melting mode" found by Walin (1993) in a 1-D model, and is characterised by an "increasing mixed-layer depth, slowly decreasing ice thickness, and small but finite stability". However, the vertical stability in our model is periodically destroyed when the density in the mixed layer becomes higher than at the top of the pycnocline. These convective events bring a large amount of relatively warm water towards the surface. This induces a strong heat flux at the ice base and hence an intense melting, which tends to re-stratify the water column. Then, ice melting weakens and the buoyancy flux becomes destabilising again. As a result, the mixed layer deepens until a new convective event occurs and so on. Such oscillations have been observed during periods of intense vertical mixing in ice-covered areas (Morawitz et al., 1996), and Gordon (1991) has included an oscillatory mode in the stages leading to the formation of offshore polynyas. The way the model represents this oscillation has been analysed by Goosse (1997) using a 1-D convection model similar to the one of Martinson et al. (1981) which mimics the behaviour of the full 3-D model during convective events with the advantage of having an analytical solution. The conclusion of this study (for more details, see Goosse (1997)) is that the mechanism simulated by the $3-\mathrm{D}$ model is 

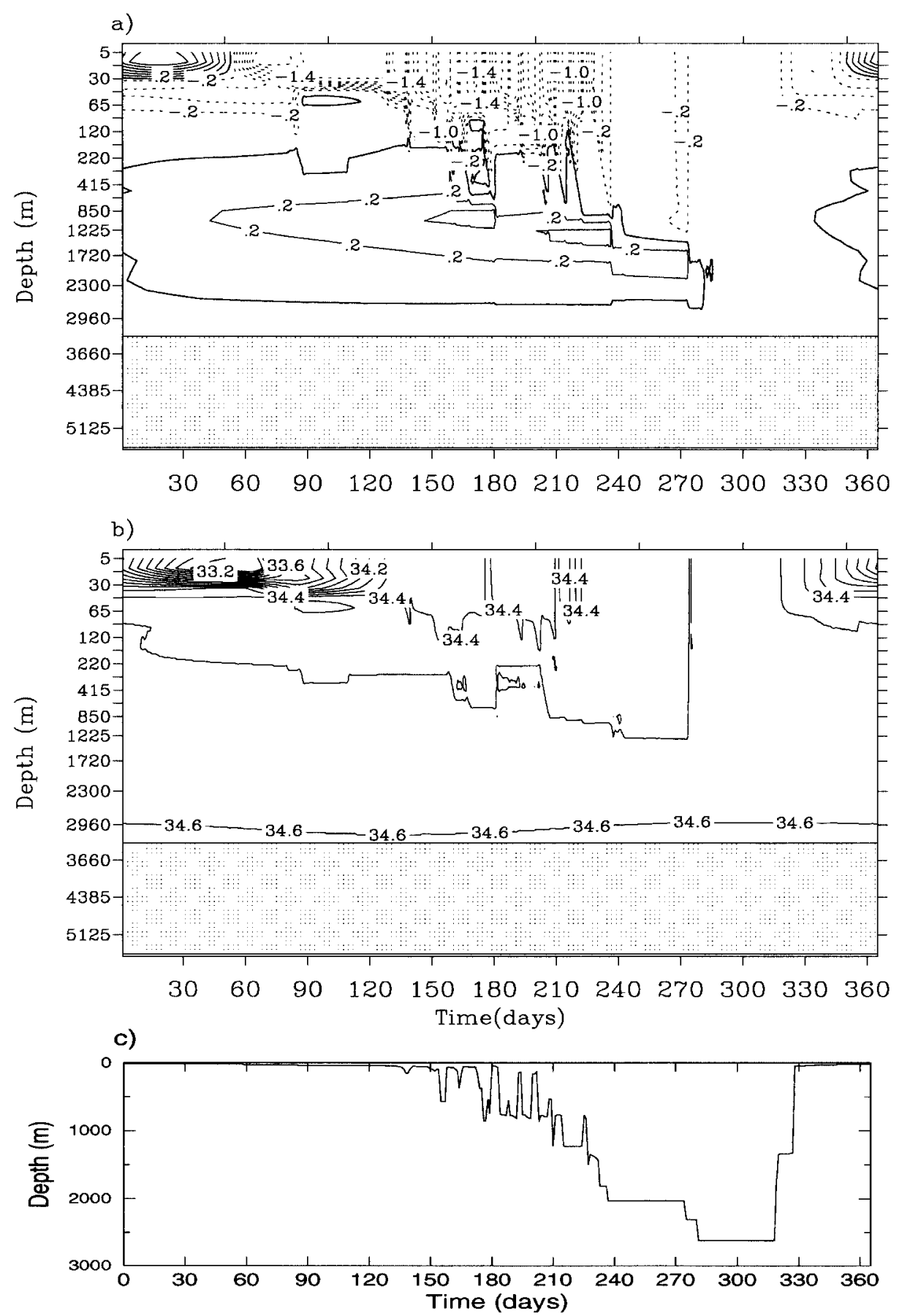

Fig. 2. Seasonal evolutions in the polynya located near the Greenwich meridian of (a) the potential temperature $\left({ }^{\circ} \mathrm{C}\right)$, (b) the salinity in psu and, (c) the mixed-layer depth defined as the depth where the potential density exceeds by $0.01 \mathrm{~kg} \mathrm{~m}^{-3}$ the surface value. 
a)

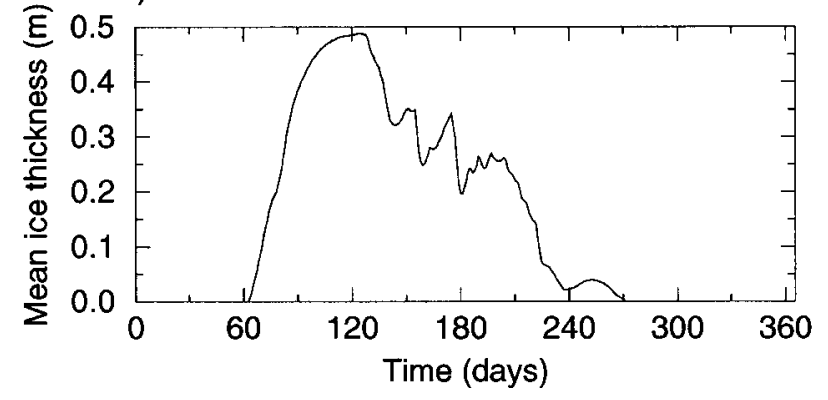

b)

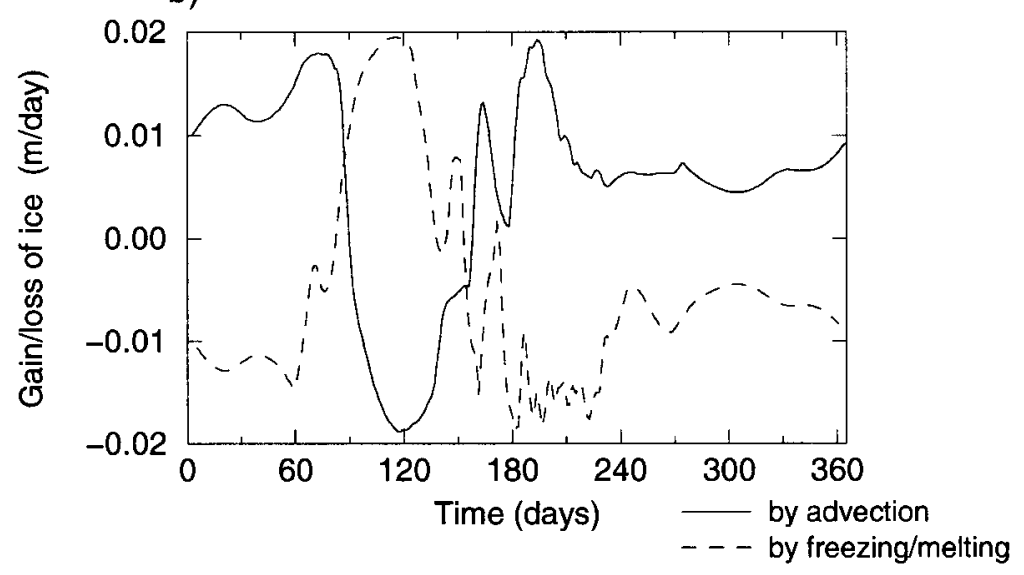

Fig. 3. (a) Seasonal evolution of the mean ice thickness in the polynya area expressed as the total ice volume divided by the area. (b) Seasonal variations of the gain/loss of ice by advection (solid line) and by local freezing/melting (dashed line) in the polynya area. Positive values correspond to ice convergence and freezing, respectively.

reasonable but the model does not simulate accurately the frequency and amplitude of the oscillation because of the coarse spatio-temporal resolution. Nevertheless, this bad representation of the characteristics of the oscillation does not have significant impact on the evolution of the polynya.

The ice has totally disappeared from the polynya area at the end of September. At that time, the equivalent of $16 \mathrm{~cm}$ of ice is imported in the polynya area per month (Fig. 3b). This ice melts locally, but the buoyancy flux associated with cooling is much higher than the one due to melting (Fig. 4). Consequently, convection continues and deepens. After day 270, the heat loss significantly decreases because of the spring warming of the atmosphere. When the buoyancy flux at surface becomes close to zero, convection stops, and a stable fresh and warm layer is formed at surface (Fig. 2).

The shift from the saline mode characteristic of the autumn and beginning of winter to the thermal mode has been achieved because of a strong salt flux at the surface mainly due to ice production. Indeed, between day 70 (when the sea-surface salinity is minimum) and day 180 (when the stratification is weak and the system is well on its way to the thermal mode), the ice production explains more than $80 \%$ of the increase in the salt content of the top $500 \mathrm{~m}$ of the water column. This corresponds to a net ice production (i.e., freezing minus melting) of $52 \mathrm{~cm}$ of ice, $47 \%$ of which is exported out of the polynya area by ice divergence during that time (Fig. 3b).

The other components of the freshwater budget of the upper $500 \mathrm{~m}$ have a smaller magnitude for 


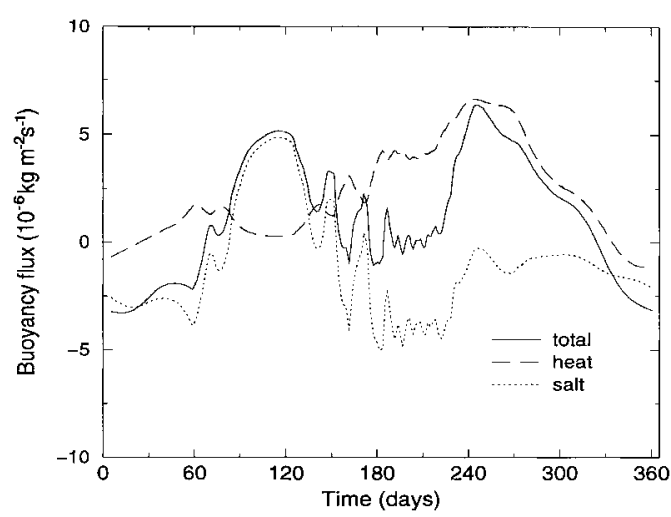

Fig. 4. Seasonal evolutions of the buoyancy flux in the polynya area (solid line). The dashed and dotted lines represent the contributions of the temperature and salinity to this buoyancy flux, respectively. They are computed by using a linearisation of the equation of state around the sea-surface salinity and temperature in the polynya area. Fluxes are positive upwards, which means that a positive value tends to destabilise the water column.

the considered period. Precipitation and evaporation through leads amounts to $+4 \mathrm{~cm}$ and $-12 \mathrm{~cm}$ of water, respectively, when averaged over the polynya area, while restoring brings the equivalent of $+11 \mathrm{~cm}$ of water. The total contribution of these three elements is thus $+3 \mathrm{~cm}$ of water between day 70 and day 180 . The exchanges of water with the shelf located southward (where the salinity is high because of the strong ice production prevailing there) contribute to an equivalent of $-9 \mathrm{~cm}$ of freshwater. Finally, the lateral exchanges with the regions where the ocean is deep and vertical exchanges with the deep ocean in the polynya area induce an equivalent flux of $-3 \mathrm{~cm}$. Nevertheless, it must be stressed that the magnitude of the various components can change strongly after day 180 . First, when convection has reached $500 \mathrm{~m}$, vertical exchanges become the main source of salt for the upper layer and explain why the sea-surface salinity continue to increase (Fig. 2b) even though freshwater is added at surface (Fig. 4). Second, when ice concentration decreases, the evaporation through leads can be a significant element of the freshwater budget. For instance, the evaporation averaged over the polynya area amounts to $9 \mathrm{~cm}$ in September, which corresponds to a realistic latent-heat flux of $98 \mathrm{~W} \mathrm{~m}^{-2}$ through leads (Andreas and Makshtas, 1985).

\section{Conditions favouring the polynya development}

In the previous section, the mechanisms that participate in the modelled polynya formation have been identified. Here, the causes of the polynya occurrence at this particular place near the Greenwich meridian are studied by means of 50 year-long sensitivity experiments starting from the end of the control simulation. In the 1st and 2nd experiments, the impact of ice-transport divergence has been tested by decreasing the wind stress by a factor 2 and 4, respectively, in a region centred over the polynya $\left(5^{\circ} \mathrm{W}-23^{\circ} \mathrm{E}, 58^{\circ}-75^{\circ} \mathrm{S}\right.$, hereafter referred to as region $\mathrm{P})$. When the wind stress is divided by 2 , the ice cover thickens significantly in fall because of the weaker ice transport, but the polynya still occurs (Fig. 5). By contrast, when the wind stress is decreased by a factor 4 , which roughly corresponds to a $50 \%$ reduction in wind speed, no polynya opens. In this case, the amount of brine rejected into the ocean, which strongly depends on the rate of ice export, is not sufficient to trigger deep convection and the subsequent polynya formation.

Several authors (Killworth, 1983; Gordon and Huber, 1990; Gordon, 1991) have suggested that upwelling in the ocean can predispose a water column to become unstable. It brings warmer and saltier water into the surface layer and hence

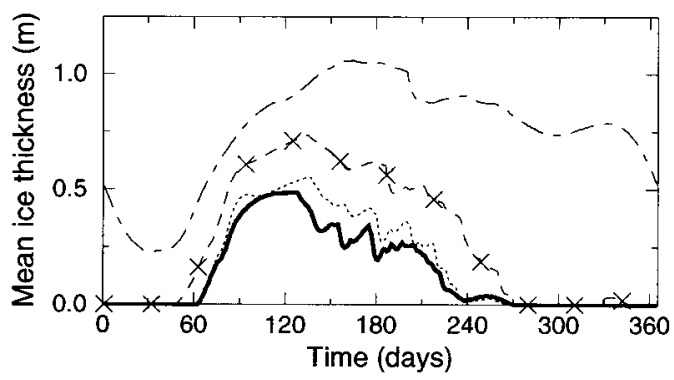

Fig. 5. Seasonal evolutions of the mean ice thickness in the polynya area in the control experiment (thick solid line) and in the sensitivity experiments in which the wind stress has been divided by 2 (dashed line with crosses), by 4 (dot-dashed line) and in which the stress at the ocean surface has been reduced by a factor 2 (dotted line). 
increases its salinity, which is a necessary condition to shift from the saline mode to the thermal mode. The associated heat can be used to melt ice, which induces a negative feedback, or can be directly ventilated to the atmosphere (see also Martinson, 1990). In the model, the vertical velocity has a mean value of about $0.1 \times 10^{-5} \mathrm{~m} \mathrm{~s}^{-1}$ in the Weddell Sea (Fig. 6) and is upward nearly everywhere except over the continental shelf. Near the Greenwich meridian, a maximum of $0.3 \times 10^{-5} \mathrm{~m} \mathrm{~s}^{-1}$ occurs. These values agree well with the estimates of Gordon and Huber (1990) for the Weddell Sea.

In the model, the upwelling is mainly winddriven, as the vertical velocities are very close to the Ekman pumping computed from the surface stress. Therefore, reducing the wind stress, as is done in the first two sensitvity experiments, has also a direct impact on the oceanic vertical velocity. In order to separate the effects of ice transport and upwelling, a third sensitivity experiment has been carried out in which only the stress at the ocean surface (in leads and below the ice) has been reduced by a factor 2 in region $\mathrm{P}$, inducing a reduction of the vertical velocity by about the same factor. In this experiment, the ice is a little thicker than in the control experiment (Fig. 5), but the polynya opens nearly at the same time. This demonstrates that a strong local oceanic upwelling is not the major cause of the polynya opening in our simulation.
We have also assessed the possible influence of the turbulent fluxes of sensible and latent heat on the polynya development by reducing by a factor 2 the wind speed used in the computation of these fluxes over region P. Results indicate that this perturbation affects the evolution of the ice thickness in the region, but does not significantly modifies the polynya formation process (Fig. 7).

In the eastern Weddell Sea, Levitus'(1982) seasurface salinities decrease smoothly from about

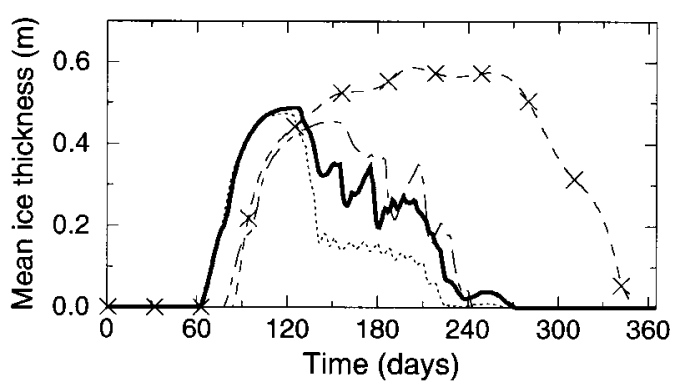

Fig. 7. Seasonal evolutions of the mean ice thickness in the polynya area in the control experiment (thick solid line) and in the sensitivity experiments in which the wind speed has been divided by 2 in the computation of sensible- and latent-heat fluxes (dot-dashed line), in which the surface salinity has been restored to the average value for the Weddell Sea (dotted line), and in which the exchanges of salt/freshwater between ice and ocean in the polynya area have been neglected (dashed line with crosses).

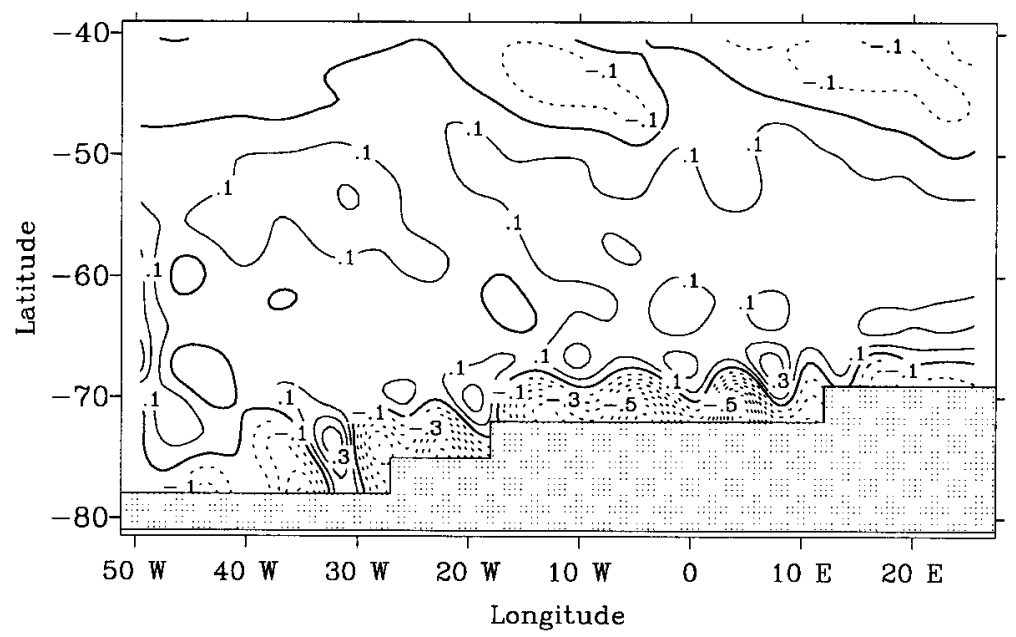

Fig. 6. Annual mean vertical velocities simulated by the model in the Weddell Sea sector at a depth of $75 \mathrm{~m}$. A positive value corresponds to upwelling. Contour interval is $0.1 \times 10^{-5} \mathrm{~m} \mathrm{~s}^{-1}$. 
$34.1 \mathrm{psu}$ at $60^{\circ} \mathrm{S}$ to about $33.7 \mathrm{psu}$ at $70^{\circ} \mathrm{S}$. In order to assess the influence of the relaxation towards those salinities, the model surface salinity in region $\mathrm{P}$ has been restored to the average value for the Weddell Sea (33.9 psu) instead of the local data as in the control run. In this experiment, the polynya formed faster than in the control run (Fig. 7) because of a lower freshwater flux associated with the restoring. Therefore, the location of the polynya is not constrained by the information included in the salinity restoring. The same conclusion is valid for precipitation, which displays no particular structure near the Greenwich meridian. These observations do not mean that the freshwater forcing is not important for the polynya formation. They reveal, however, that special features in the restoring or precipitation fields do not determine the location of the modelled polynya.

If the salt/freshwater exchanges between ice and ocean are neglected in the polynya area, the ice formation is no longer associated with a destabilisation of the water column. This leads to a much weaker oceanic heat flux at the ice base, and consequently, no polynya forms (Fig. 7). This confirms the fact that, even if the wind-driven icetransport divergence is essential for the polynya opening, our polynya is not simply a latent-heat one. The sensible heat provided by the ocean is also of prime importance. In order to transfer such a large amount of heat to the surface by convection, the ocean needs a sufficiently large heat source at depth. Regarding this point, the area close to the Greenwich meridian is particularly well located, since warm water is supplied by a direct inflow of Circumpolar Deep Water (CDW) from the ACC to the Weddell Gyre (Fig. 8), and this in general agreement with observations (Orsi et al., 1993). The signature of this strong inflow is also apparent in Fig. 2 as a temperature increase of more than $0.3^{\circ} \mathrm{C}$ in the depth range 500-2000 $\mathrm{m}$ between January and the beginning of winter.

It has been suggested that the Maud Rise, a seamount whose top is at a depth of about $2000 \mathrm{~m}$ compared to the 5000-m-deep surrounding ocean, could have an influence on the location of the polynya (Gordon and Huber, 1990; Gordon, 1991; Bersh et al., 1992; De Veaux et al., 1993; Alverson and Owens, 1996). Unfortunately, the influence of this topographic feature is not taken into account in the model since Maud Rise has a too small scale to be represented at the coarse resolution used here. It corresponds only to a region of smaller depth $(3800 \mathrm{~m})$. In the model, the removal of this feature has nearly no impact on the polynya formation.

\section{Comparison with observations}

In this section, we compare the model polynya to those observed in the Weddell Sea sector. The

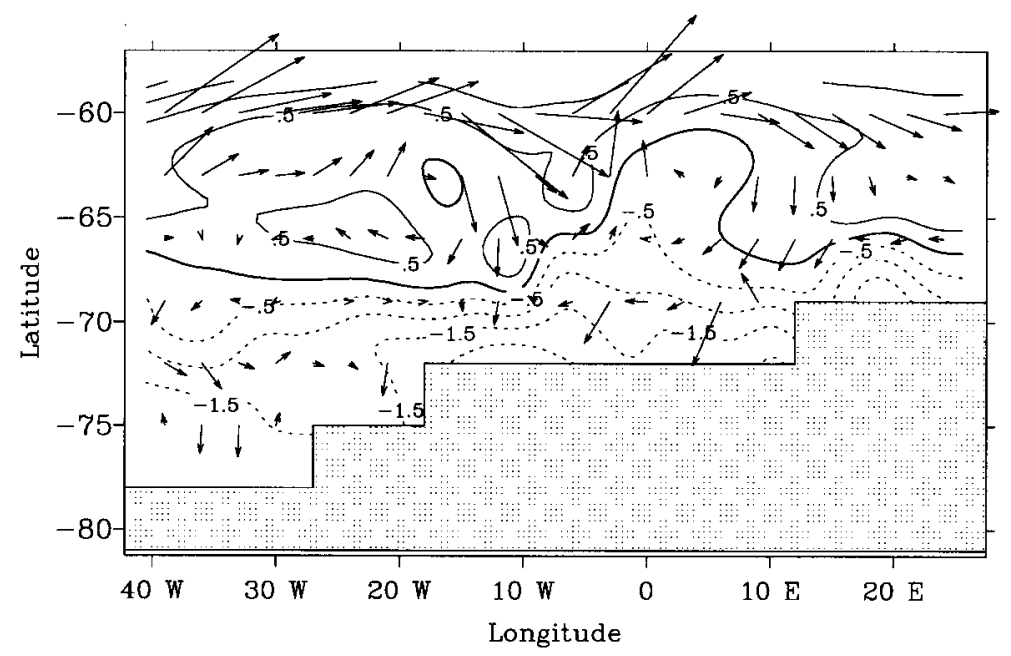

Fig. 8. Annual mean potential temperatures $\left({ }^{\circ} \mathrm{C}\right)$ and horizontal velocities in the Weddell Sea sector at a depth of $120 \mathrm{~m}$ from the control run. The maximum vector corresponds to a speed of $11.8 \mathrm{~cm} \mathrm{~s}^{-1}$. 
simulated polynya is somewhat different from the Weddell polynya present three consecutive years in the 1970s. First, our polynya is about a factor 5 smaller in size than this exceptional feature. Second, the Weddell polynya stayed open nearly all winter long, while in the model, the polynya area is first covered by ice, the ice concentration then decreases gradually until a complete opening of the polynya occurs at the end of September. There is a degree of resemblance between the simulated polynya and the observed Maud Rise polynya. However, the latter is usually open only during a few days to a few weeks. Furthermore, the polynya occurs each year in the model, whereas the Maud Rise polynya is present only during particular years. The area located near the Greenwich meridian is also characterised by an earlier ice melting than surrounding areas, leading to the development of a spring polynya at the end of October-beginning of November nearly each year (Comiso and Gordon, 1987). Nevertheless, this is more than 1 month later than in the model. This comparison shows that, even if large areas of open water inside the pack have been frequently observed near the Greenwich meridian, the model overestimates significantly this area, at least on average over the period covered by satellite observations.

The main reason why the model generates polynyas every year at the same place, in disagreement with observations, is related to the use of climatological atmospheric conditions, with the same forcing repeated each year. To verify this assertion, a sensitivity experiment has been conducted in which the model was driven by the wind stresses of the period 1980-1989 from which the climatological fields used in the control run were derived (Trenberth et al., 1989). The other forcing components were the same as in the control run. The model was integrated for 50 years from the end of the control simulation with the same forcing repeated every 10 years.

As shown in Fig. 9a, the mean ice thickness in the polynya area over the last 10 years of the sensitivity run is generally much higher than in the control simulation. An extensive, long-lived polynya is only present in the first year of the sensitivity experiment. During this particular year, the Trenberth et al.'s (1989) data present in autumn and early winter very strong southeasterly winds in the polynya area (Fig. 10a).
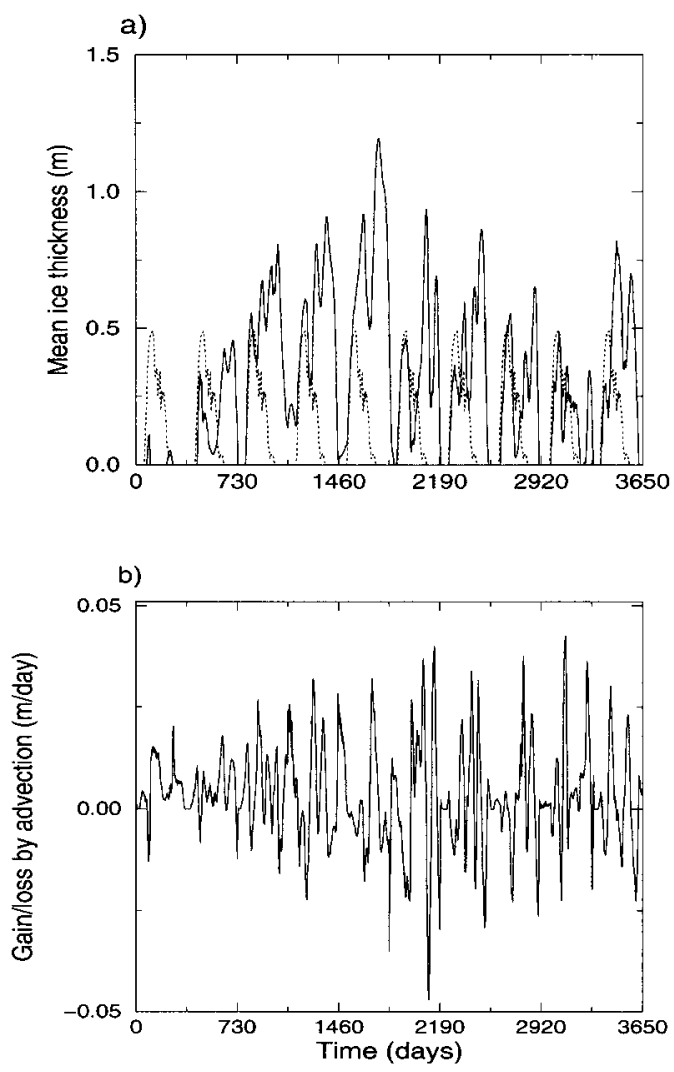

Fig. 9. (a) Time evolutions of the mean ice thickness in the polynya area from the experiment forced by wind stresses of the period 1980-1989 (sold line) and from the control run (dashed line, same curve as Fig. 3a). (b) Variations of the gain/loss of ice by advection in the experiment forced by wind stresses of the period 1980-1989.

These winds favour the polynya opening since they induce a rapid export of the ice formed locally, while they bring to the polynya area relatively thin ice originating from the coastal regions of the eastern Weddell Sea. The second, sixth, eighth, and ninth years of the sensitivity run, which display short periods in early winter with low mean ice thickness (Fig. 9a), present also south-easterly winds in the polynya area. Nevertheless, the polynya is not completely open since the wind-stress intensity during those years is at least a factor 2 smaller than in the first year (although the wind stresses there are still strong compared to the ones observed at other locations in the Southern Ocean). During the other years, 

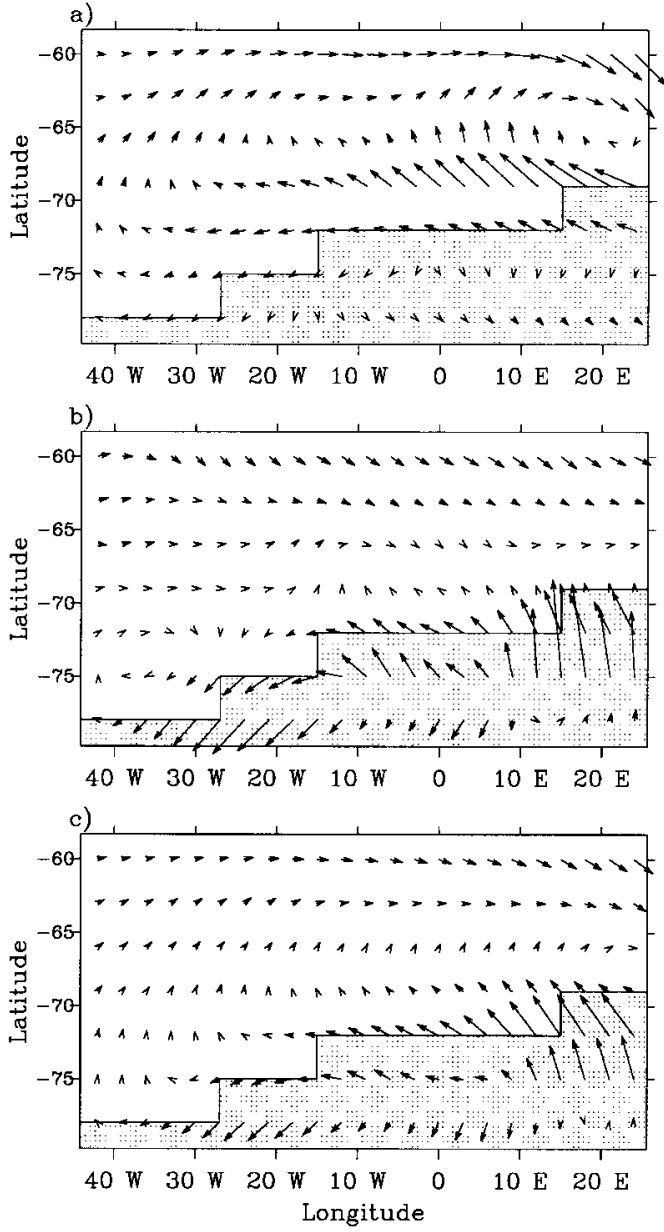

Fig. 10. April-May-June wind stresses over the Weddell Sea sector. (a) for the year 1980, (b) for the year 1989, and (c) averaged over the period 1980-1989. The maximum vector corresponds to a stress of $0.23 \mathrm{~N} \mathrm{~m}^{-2}$.

the weak south-easterly winds and moderate south-westerly winds (Fig. 10b) are not able to induce a decrease of the mean ice thickness in winter below a value of $0.20 \mathrm{~cm}$.

The wind-stress climatology over the 10 years exhibits south-easterly winds in the polynya area (Fig. 10c). They have roughly the same magnitude as during the years which have a smallduration polynya in the sensitivity experiment. Nevertheless, the polynya stays open much longer in the control run. One major reason for this difference is that, because of the 10 year average, the climatological mean does not incorporate the events of strong wind-induced ice transport convergence (Fig. 9b) which are able to prevent a complete opening of the polynya. For instance, during the ninth year, the ice-transport convergence reaches the equivalent of $0.04 \mathrm{~m} \mathrm{day}^{-1}$, while the maximum in the control run is of $0.02 \mathrm{~m} \mathrm{day}^{1}$. This brings large amount of ice in the polynya area which rapidly melts, suppresses convection, and induces an increase of the mean ice thickness.

In addition to the wind stress, other effects (although weaker) contribute to the overestimation of the polynya extent and duration in the control experiment. A first one is the memory of the ice-ocean system that favours the opening of a polynya at the place where a polynya developed the preceding year by the following mechanism (Martinson et al., 1981). The convection has generated a nearly homogenous water column which becomes only marginally stable during summer (Fig. 2). Therefore, a suitable forcing the following year (as it is the case every year when using a climatological forcing) is able to destablise this preconditioned area and to induce the opening of a polynya. With interannual variability included, the forcing at this location may be not sufficient the following year to destabilise even a marginally stable water column. The stratification of the water column would then increase, and a more vigorous forcing would be necessary to create a polynya the subsequent year. The importance of this effect has been assessed by means of a oneyear simulation forced by the wind stresses of the second year of the sensitivity experiment but starting from the end of year 5 (which displays an extensive winter ice cover) instead of the end of year 1 (in which a large polynya has occurred). In this simulation, the minimum ice thickness in winter amounts to $12 \mathrm{~cm}$, compared to $4 \mathrm{~cm}$ in the sensitivity run (Fig. 5).

A second contributor is the too weak model stratification in the Southern Ocean (Fig. 11) compared to the already low observed one (Gordon, 1981). As a consequence, vertical mixing is less constrained by the stratification than in the real world, and the deepening of the mixed layer is faster, leading to a too strong and too rapid ice melting. This low density at depth in the Southern Ocean is a problem common to a large number of large-scale ice-ocean models (Legutke et al., 1997; Stössel et al., 1998). It does not explain why 


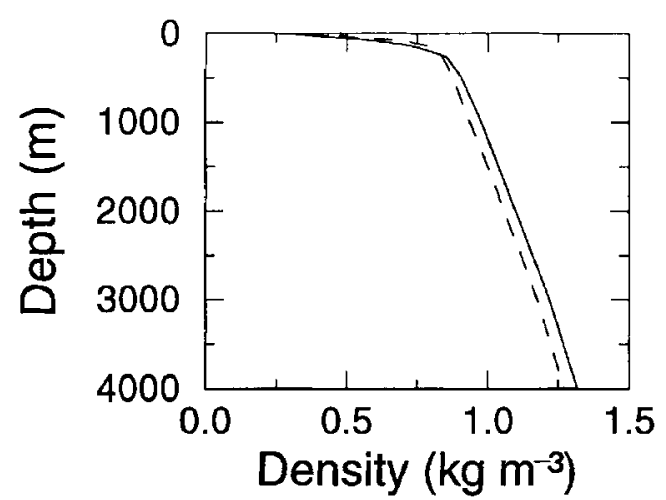

Fig. 11. Annual mean vertical profiles of zonally averaged density relative to a reference water mass $\left(0^{\circ} \mathrm{C}\right.$, $34 \mathrm{psu}$ ) at $67^{\circ} \mathrm{S}$ as simulated by the model (dashed line) and as observed following Levitus (1982) (solid line).

convection occurs in a particular location surrounded by relatively well stratified regions. But, it plays certainly a role in the tendency of the model to overestimate the size and duration of polynya events since it provides a kind of preconditioning of the whole model Southern Ocean for polynya formation.

A third contributor to the overestimation of the polynya extent and duration is the coarse spatial resolution of the model. The polynya area increases with the square of the mean radius, while the ice edge through which ice can be transported in the polynya area grows linearly with the radius. As a result, the larger the polynya, the greater must be the inflow rate to cover the whole polynya area and suppress convection. Following this reasoning, Comiso and Gordon (1987) have suggested that large polynyas can survive significantly longer than small ones. They propose a diameter of $100 \mathrm{~km}$ as a minimum size to protect the convection against the freshwater inflow through the sides, except in case of very strong ice advection. In the model, the minimum size of polynyas is dictated by the resolution, because convection must cover at least one grid point. This corresponds to an area of $150-300 \mathrm{~km}$ at this latitude, larger than the critical size proposed by Comiso and Gordon (1987).

\section{Impact of the polynya on deep waters}

The oceanic convection in the polynya area participates in the Weddell Sea deep-water renewal by injecting water with a temperature of about $0^{\circ} \mathrm{C}$ and a salinity of $34.54 \mathrm{psu}$ at depths greater than $2000 \mathrm{~m}$ (Fig. 2a,b). This water has a temperature close to the one measured in a deep chimney present in the Weddell Sea in 1977 (Gordon, 1978), but is more than $0.05 \mathrm{psu}$ fresher. The other source of deep water at these latitudes is the sinking along the Antarctic continental margins of a mixture of different water types including salty shelf water and CDW (Foster and Carmack, 1976; Gordon, 1991). In accordance with observations (Gordon, 1978, 1982), the deep waters formed by this latter mechanism in the model are denser than the ones produced by open-ocean convection because they have a slightly higher salinity and a temperature well below $0^{\circ} \mathrm{C}$ close to their region of formation (Fig. 12).

In order to visualise the path followed by the water mass produced in the polynya area, the control run has been pursued during 300 years with a passive tracer included in the model. At the surface, the tracer concentration of this tracer at the surface was restored with a time scale of 4 days to a value of 1 in the polynya region (see Section 2) and 0 elsewhere. Thus, a continuous source of tracer exists in the polynya area at the surface, while a sink of tracer is applied at the remaining ocean surface (Cox, 1989). No subsurface restoring is used on the tracer concentration. After this 300-year integration, the tracer concentration in the South Atlantic was approximately equilibrated.

At $2300 \mathrm{~m}$, i.e., the deepest level reached by convection, the concentration has logically a maximum in the polynya area (Fig. 13a) since a direct import of tracer from the surface occurs there. The tracer-tagged water is then transported westwards by the Weddell Gyre and mixes with ambient water masses, which include the deep water formed along the continental margins of Antarctica. A weaker eastward penetration towards the Indian sector of the Southern Ocean is also noticed. However, the tracer is mainly confined southwards of the Drake Passage (Fig. 12a), because the ACC is an efficient barrier to meridional mass exchanges (Gill and Bryan, 1971; Cox, 1989).

Besides, at the first level where the Drake Passage is closed $(3660 \mathrm{~m})$, a western boundary current develops in our simulation along the Scotia Ridge (Fig 13b), in qualitative agreement 


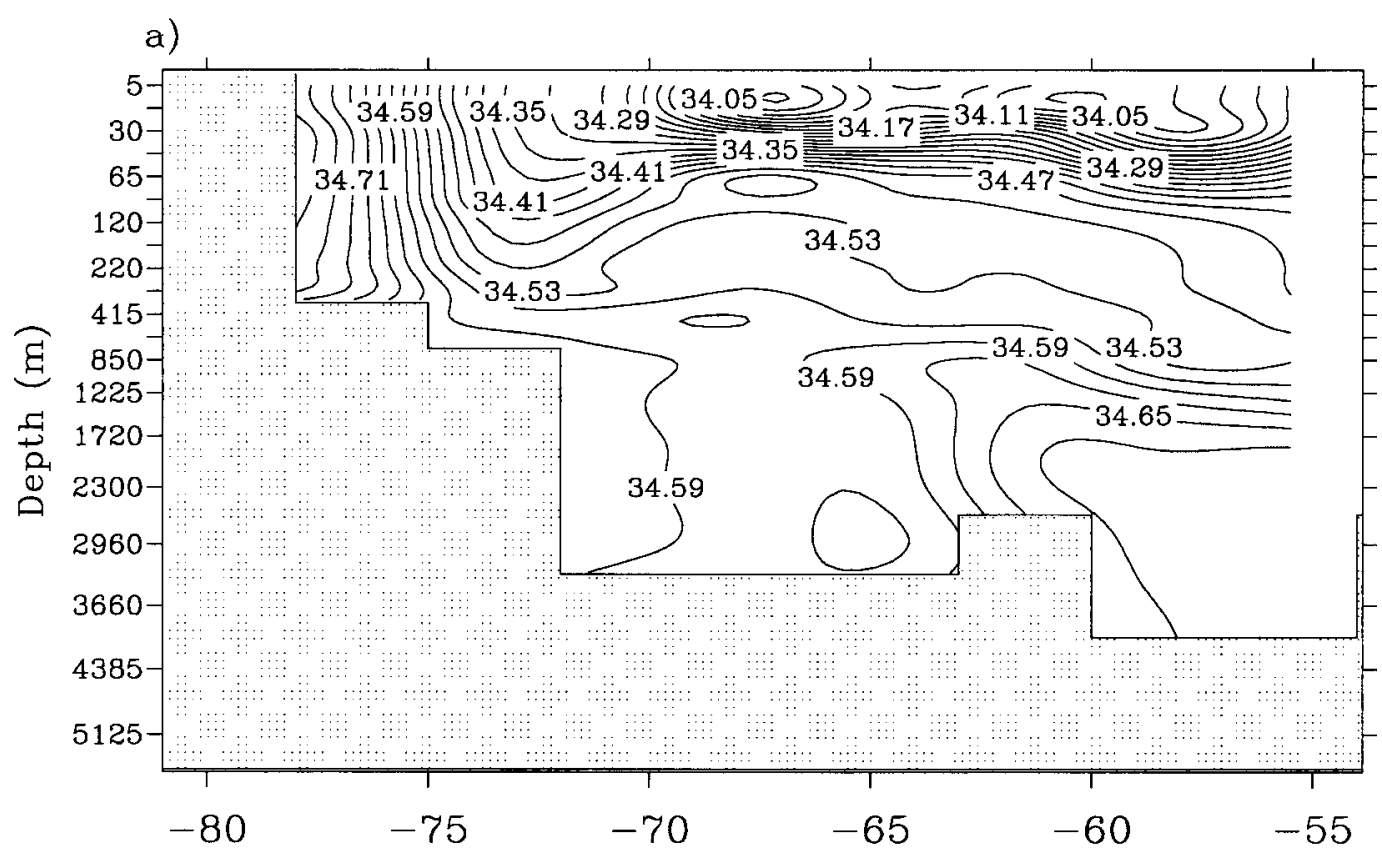

b)

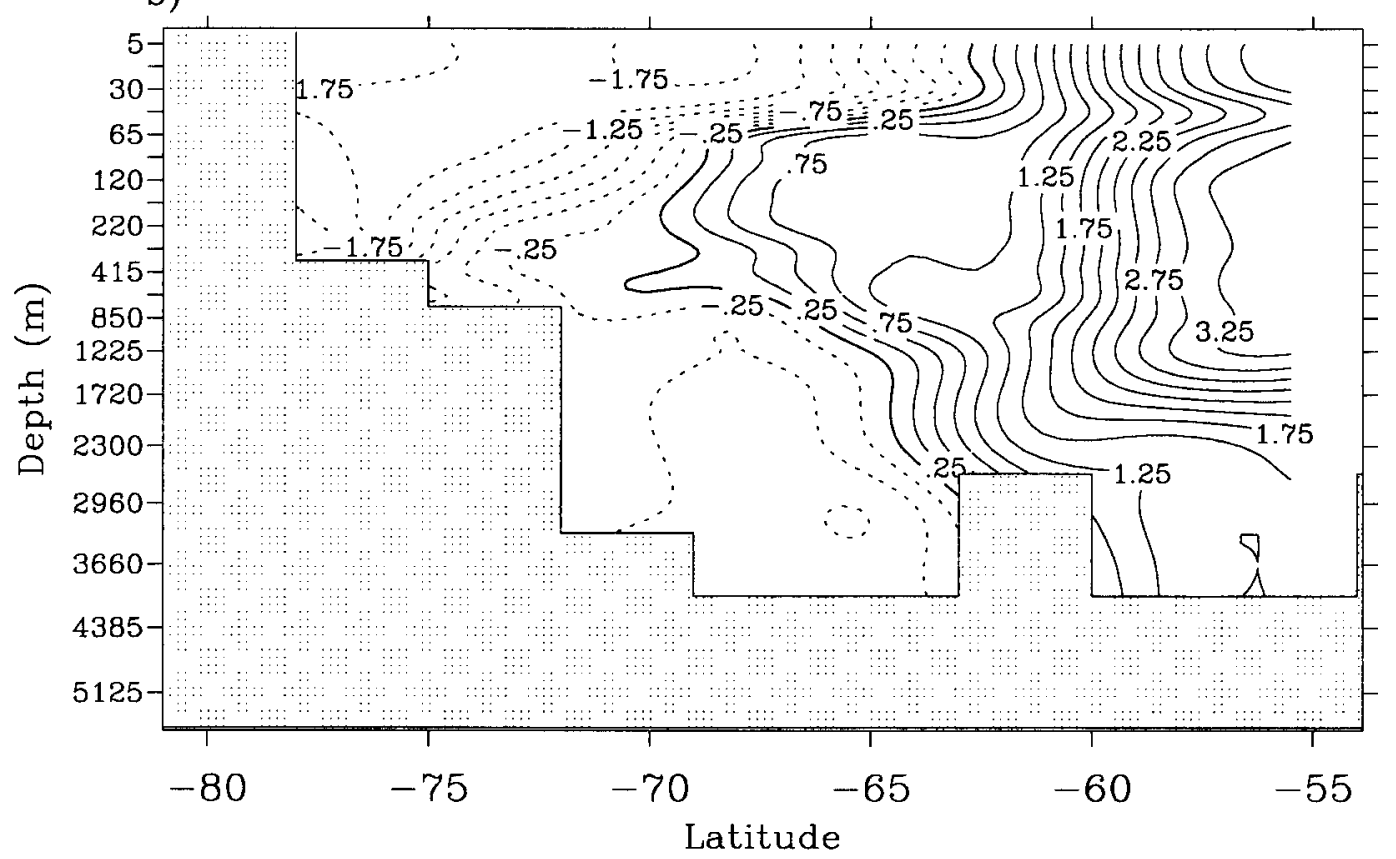

Fig. 12. Meridional section of (a) salinity and (b) potential temperature in the model Weddell Sea at $50^{\circ} \mathrm{W}$. Contour intervals are $0.03 \mathrm{psu}$ and $0.2^{\circ} \mathrm{C}$, respectively. 

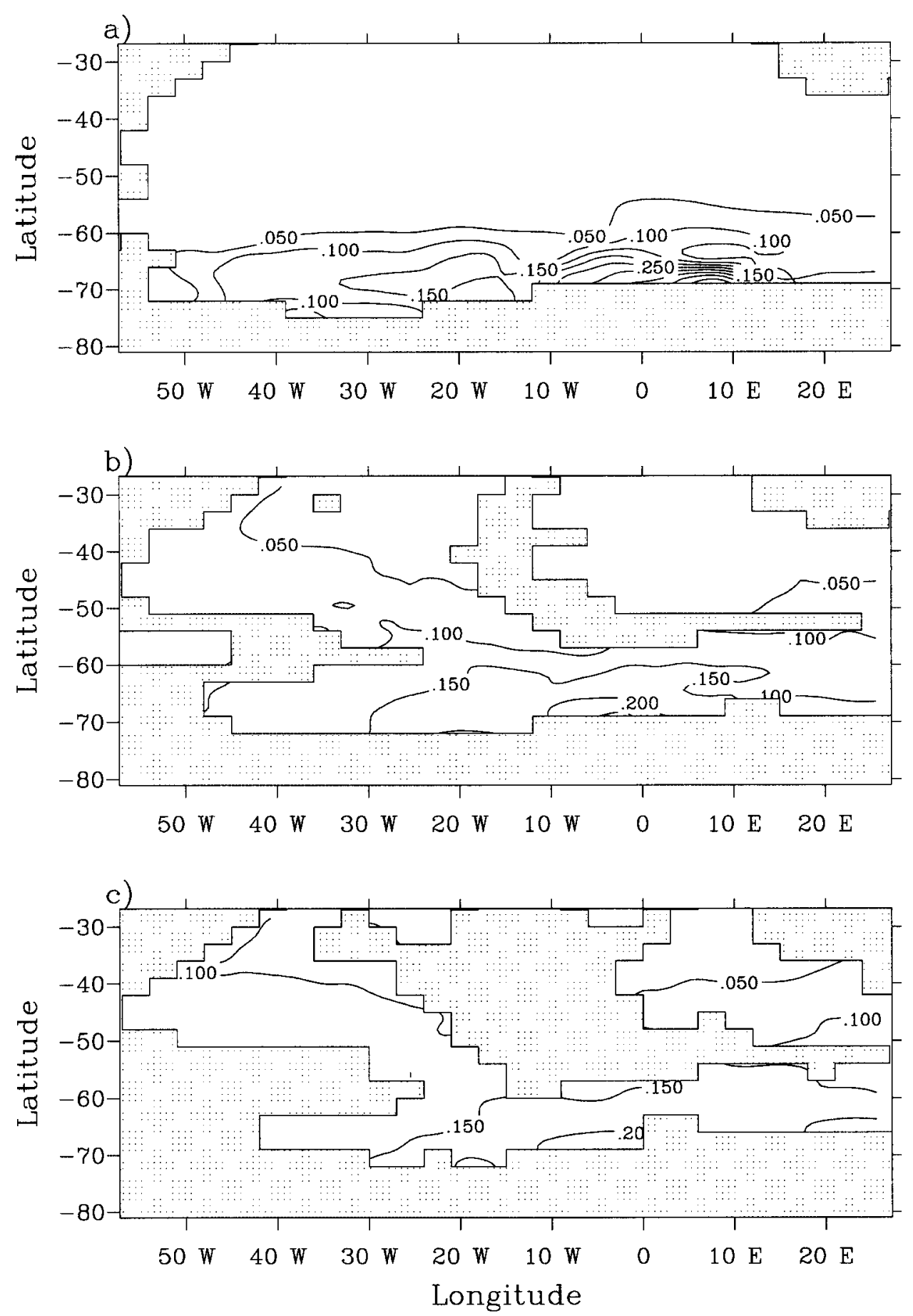

Fig. 13. Concentrations in the southern Atlantic of the passive tracer released at the surface in the polynya area (a) at $2300 \mathrm{~m}$, (b) at $3660 \mathrm{~m}$, and (c) at $4385 \mathrm{~m}$. Contour interval is 0.05 .

Tellus 53A (2001), 1 
with observations (Whitworth et al., 1991; Gordon, 1991). This current transports northwards into the Argentina Basin the water formed in the polynya area, which thus takes part in the renewal of the Antarctic Bottom Water (AABW) in the South Atlantic. The tracer concentration in the Argentina Basin still has a maximum near the western boundary, but as the western boundary current is relatively diffuse and presents recirculations in the model, the zonal gradients are relatively weak. A small amount of the tracertagged water also invades the Atlantic east of the mid-ocean ridge.

At $3660 \mathrm{~m}$, the influence of the southward flowing North Atlantic Deep Water is still strong, thus restricting the northward propagation of the waters of Southern Ocean origin. This influence is much weaker at the next model level, i.e., at $4385 \mathrm{~m}$. As a consequence, the tracer concentration in the South Atlantic at this depth is about a factor 2 higher than at $3660 \mathrm{~m}$ (Fig. 13c).

These results reveal that the polynya contributes significantly to the renewal of deep water in the Weddell Sea, with tracer concentrations generally between $10 \%$ and $20 \%$ there. The tracer propagation to remote regions in the Southern Ocean and to the other oceanic basins becomes important at great depths $(>3660 \mathrm{~m})$. For instance, the concentration at $4385 \mathrm{~m}$ is still higher than $10 \%$ in the Argentina Basin at $40^{\circ} \mathrm{S}$. These values are only indicative because of the model limitations, but they suggest that open-ocean convection taking place in offsore polynyas is potentially a powerful mechanism for deep-water renewal.

\section{Summary and conclusions}

The sequence of events leading to the opening of a polynya near the Greenwich meridian in the CLIO model can be described as follows. (1) The stability of the upper ocean in the polynya region is high in summer as a result of ice melting, while the stratification below the seasonal pycnocline is much weaker. (2) In autumn, the salinity of the surface layer increases owing to the brine release during ice formation, inducing a mixed-layer deepening. (3) When the stable surface layer has been removed, the mixed-layer deepening is faster. It brings relatively warm water to the surface, which tends to melt the ice. Nevertheless, the net buoyancy flux is still destabilising since the intense cooling is able to counteract the stabilising effect of the freshwater flux, and thus convection persists. (4) This situation continues until ice disappears. At this time, the instability is caused by the cooling of the warm, salty deep water which is incorporated in the surface layer by convection. (5) Convection stops in spring when the cooling is no longer vigorous enough to destabilise the water column.

The sensitivity experiments performed with the model show that the polynya is formed at this particular location near the Greenwich meridian because of the conjunction of two factors. The first one is the presence of south-easterly winds in this area which are among the strongest of the Southern Ocean in the model. They induce an icetransport divergence which leads to an enhanced local ice production and brine release and then to a destabilisation of the water column. When the air-ice stress is significantly reduced (a factor 4 in our sensitivity study), the amount of brine rejected into the ocean is not sufficient to trigger deep convection and no polynya forms. It should be mentioned that ice divergence occurs only in fall in the polynya area. During the rest of the year, convergence prevails. This induces a freshwater import in the polynya area which has a stabilizing effect on the water column. Nevertheless, the convection is already well established at the end of fall and is maintained throughout the winter because of the strong atmospheric cooling. The second factor that explains the polynya formation is a direct inflow at depth near the Greenwich meridian of relatively warm water originating from the ACC. This water is then transported to the ocean surface by convection and is thus responsible for the strong upward heat flux in the ocean observed during the different phases of the polynya formation. In a sensitivity experiment, the polynya was unable to form when this vertical heat flux has been artificially reduced.

The polynya is localised in a region where recurring polynyas have been observed, and which is characterised by an earlier melting in spring than surrounding areas. This gives credibility to our results, but the modelled polynya is wider and more persistent than the observed ones. Futhermore, the model polynya occurs each year at the same location, while observed polynyas are episodic and less regular. This is due to the absence 
of interannual variability in the atmospheric forcing used in the control run. When driving the model with the wind stresses of the period 1980-1989 (from which the climatological fields utilised in the control case were derived), an extensive and long-lived polynya is only formed one year. Small-duration polynyas are present during four other years, while in the remaining five years, the forcing is not able to induce the opening of any polynya in the eastern Weddell Sea.

The overestimation of the polynya extent and duration in the model is also partly due to the fact that the stratification of the deep Southern Ocean is too weak, which promotes unrealistic downward penetration of the mixed layer. The coarse horizontal resolution of the model can also play a direct role. Indeed, the minimum size of polynyas is one model grid cell ( $\sim 150 \mathrm{~km} \times 300 \mathrm{~km}$ at this latitude), which is already large compared to observed polynyas. Furthermore, it has been shown that large polynyas have a higher probability of surviving for a long time than smaller ones.

In addition to local conditions, the polynya formation at a particular location is influenced by the large-scale distribution of density and ocean currents in the Southern Ocean. Any modification in the forcing or in the various parameterizations used in the model which affect the density structure could also have an impact on the polynya. For instance, Goosse et al. (1999) performed a simulation very similar to the control run of the present study (their experiment TUR), except that the model was forced by the precipitation rates from Jaeger (1976) instead of those from Xie and Arkin (1996). In this experiment, the polynya near the Greenwich meridian opens only at the beginning of November (spring polynya). The delay is due to the generally higher precipitation rates of Jaeger (1976). This induces a more stable water column in the eastern Weddell Sea, even though at the precise location of the polynya, the precipitation rates are slightly lower than in Xie and Arkin's (1996) climatology.
Convection in the polynya area has a significant impact on deep-water renewal in the model. This newly formed deep water remains mainly in the Weddell Gyre down to the depth where the Drake passage is closed $(3660 \mathrm{~m}$ in the model). Below this depth, the water can be exported northwards as a contributor to the inflow of AABW into the Atlantic and, to a smaller extent, into the other basins. A more precise comparison of the amounts of $\mathrm{AABW}$ formed by open-ocean convection and along the continental slope of Antarctica in the model will be performed in the near future. The quantitative results of our simulation must be taken with caution. But, they suggest that openocean convection could be a significant source of $\mathrm{AABW}$ in the real ocean, at least during years when large-scale polynyas are observed.

\section{Acknowledgements}

We want to thank J.-M. Campin, H. Cattle, D. Martinson, M. A. Morales Maqueda, A. Stössel, and B. Tartinville for helpful discussions about various aspects of this work. The comments and suggestions of two anonymous referees were very much appreciated. H. Goosse and T. Fichefet are Senior Research Assistant and Research Associate at the National Fund for Scientific Research (Belgium), respectively. This work was done within the scope of the Global Change and Sustainable Development Programme (Belgian State, Prime Minister's Services, Federal Office for Scientific, Technical, and Cultural Affairs, Contract CG/DD/09A), the Convention d'Actions de Recherche Concertées ARC 97/02-208 (Communauté Française de Belgique), and the Environment and Climate Programme (European Commission, contract ENV4-CT95-0102). All these funding agencies are gratefully acknowledged. We are also thankful to Météo-France (Toulouse) for having provided us with computing time on its Cray-J90.

\section{REFERENCES}

Andreas, E. L. and Makshtas, A. P. 1985. Energy exchange over Antarctic sea ice in the spring. J. Geophys. Res. 90, 7199-7212.

Alverson, K. and Owens, W. B. 1996. Topographic pre- conditioning of open-ocean deep convection. J. Phys. Oceanogr. 26, 2196-2213.

Baumgartner, A. and Reichel, E. 1975. The world water balance. Elsevier, Amsterdam, 179 pp.

Tellus 53A (2001), 1 
Berliand, M. E. and Strokina, T. G. 1980. Global distribution of the total amount of clouds (in Russian). Hydrometeorological Pub. House, Leningrad, 71 pp.

Bersch, M. 1988. On deep convection in the Weddel Gyre. Deep-Sea Res. 35, 1269-1296.

Bersch, M., Becker, G. A., Frey, H. and Koltermann, K. P. 1992. Topographic effects of the Maud Rise on the stratification and circulation of the Weddell Gyre. Deep-Sea Res. 39, 303-331.

Bromwich, D. H., Chen, B. and Hines, K. M. 1998 Global atmospheric impacts induced by year-round open water adjacent to Antarctica. J. Geophys. Res. 103, 11,173-11,189.

Bryan, K. and Lewis, L. J. 1979. A water mass model of the World Ocean. J. Geophys. Res. 84, 2503-2517.

Budd, W. F. 1991. Antarctica and global change. Clim. Change 18, 272-299.

Campin, J. M. and Goosse, H. 1999. Parameterization of density-driven downsloping flow for a coarseresolution ocean model in $z$-coordinate. Tellus $\mathbf{5 1 A}$ 412-430.

Carsey, F. D. 1980. Microwave observation of the Weddell polynya. Mon. Wea. Rev. 108, 2032-2044.

Comiso, J. C. and Gordon, A. L. 1987. Recurring polynyas over the Cosmonaut Sea and the Maud Rise. J. Geophys. Res. 92, 2819-2833.

Comiso, J. C. and Gordon, A. L. 1996. Cosmonaut polynya in the Southern Ocean: Structure and variability. J. Geophys. Res. 101, 18,297-18,313.

Cox, M. 1989. An idealized model of the World Ocean Part I: The global-scale water masses. J. Phys. Oceanogr. 19, 1730-1752.

Crutcher, H. L. and Meserve, J. M. 1970. Selected level heights, temperatures and dew points for the Northern Hemisphere. NAVAIR Rep. 50-1C-52, revised, Nav. Weather Serv. Command, Washington, D.C., 98 pp.

De Veaux, R. D., Gordon, A. L., Comiso, J. C. and Bacherer, N. E. 1993. Modeling of topographic effects on Antarctic sea ice using multivariate adaptative regression splines. J. Geophys. Res. 98, 20,307-20,319.

Foster, T. D. and Carmack, E. C. 1976. Frontal zone mixing and Antarctic Bottom Water formation in the southern Weddell Sea. Deep-Sea Res. 23, 301-317.

Gill, A. E. and Bryan, K. 1971. Effect of geometry on the circulation of a three-dimensional Southern Hemisphere ocean model. Deep-Sea Res. 18, 685-721.

Gloersen, P., Campbell, W. J., Cavalieri, D. J., Comiso, J. C., Parkinson, C. L. and Zwally, H. J. 1992. Arctic and Antarctic sea ice, 1978-1987: Satellite passivemicrowave observations and analysis. NASA SP-511, Washington, D.C, 290 pp.

Goosse, H. 1997. Modelling the large-scale behaviour of the couped ocean-sea-ice system. Ph.D. thesis, Univ. Cat. Louvain, Louvain-la-Neuve, Belgium, 231 pp.

Goosse, H., Campin, J. M., Fichefet, T. and Deleersnijder, E. 1997. The impact of sea-ice formation on the properties of Antarctic Bottom Water. Ann. Glaciol. 25, 276-281.

Goosse, H., Deleersnijder, E., Fichefet, T. and England,
M. H. 1999. Sensitivity of a global coupled ocean-sea ice model to the parameterization of vertical mixing. J. Geophys. Res. 104, 13,681-13,695

Gordon, A.L. 1978. Deep Antarctic convection west of Maud Rise. J. Phys. Oceanogr. 8, 600-612.

Gordon, A. L. 1981. Seasonality of Southern Ocean sea ice. J. Geophys. Res. 86, 4193-4197.

Gordon, A. L. 1982. Weddell Deep Water variability. J. Mar. Res. 40 (suppl.), 199-217.

Gordon, A. L. 1991. Two stable modes of Southern Ocean winter stratification. In: Deep convection and deep water formation in the oceans (ed. P. C. Chu and J. C. Gascard). Elsevier Oceanography Series 57, Elsevier, Amsterdam, 17-35.

Gordon, A. L. and Huber, B. A. 1990. Southern Ocean winter mixed layer. J. Geophys. Res. 95, 11,655-11,672.

Grabs, W., De Couet, T. and Pauler, J. 1996. Freshwater fluxes from continents into the world oceans based on data of the global runoff data base. Global Runoff Data Centre Rep. 10, Fed. Inst. of Hydrol., Koblenz, Germany, $228 \mathrm{pp}$.

Häkkinen, S. 1995. Seasonal simulation of the Southern Ocean coupled ice-ocean system. J. Geophys. Res. 100 22,733-22,748.

Hellerman, S. and Rosenstein, M. 1983. Normal monthly wind stress over the World Ocean with error estimates. J. Phys. Oceanogr. 13, 1093-1104.

Jaeger, L. 1976. Monatskarten des niederschlags für die ganze erde (in German). Ber Dtsch Wetterdienstes 18 , No. 139.

Killworth, P. D. 1983. Deep convection in the World Ocean. Rev. Geophys. Space Phys. 21, 1-26.

Legutke, S., Maier-Reimer, E., Stössel, A. and Hellbach, A. 1997. Ocean-sea-ice coupling in a global ocean general circulation model. Ann. Glaciol. 25, 116-120.

Levitus, S., 1982. Climatological atlas of the World Ocean. NOAA Prof. Pap. 13, U.S. Gov. Print. Office, Washington, D.C., 173 pp.

Martinson, D. G. 1990. Evolution of the Southern Ocean winter mixed layer and sea ice: Open ocean deepwater formation and ventilation. J. Geophys. Res. 95, 11,641-11,654.

Martinson, D. G., Killworth, P. D. and Gordon, A. L. 1981. A convective model for the Weddell polynya. J. Phys. Oceanogr. 11, 466-488.

Mellor, G. L. and Yamada, T. 1982. Development of a turbulence closure model for geophysical fluid problems. Rev. Geophys. Space Phys. 20, 851-875.

Motoi, T., Ono, N. and Wakatsuchi, M. 1987. A mechanism for the formation of the Weddell polynya in 1974 J. Phys. Oceanogr. 17, 2241-2247.

Morawitz, W. M. L., Sutton, P. J., Worcester, P. F. and Cornuelle, B. D. 1996. Three-dimensional observations of a deep convective chimney in the Greenland Sea during winter 1988/1989. J. Phys. Oceanogr. 26, 2316-2343.

Muench, R. D. 1991. Relict convective features in the Weddell Sea. In: Deep convection and deep water forma- 
tion in the oceans (ed. P. C. Chu and J. C. Gascard) Elsevier Oceanography Series 57, Elsevier, Amsterdam, 53-67.

Orsi, A. H., Nowlin, W. D. and Whitworth, T. 1993. On the circulation and stratification of Weddell Gyre Deep-Sea Res. 40, 169-203.

Smith, S. D., Muench, R. D. and Pease, C. H. 1990. Polynyas and leads: An overview of physical processes and environment. J. Geophys. Res. 95, 9461-9479.

Stössel, A., Kim, S. J. and Drijfout, S. S. 1998. The impact of Southern Ocean sea ice in a global ocean model J. Phys. Oceanogr. 28, 1999-2018.

Taljaard, J. J., van Loon, H., Crutcher, H. L. and Jenne, R. L. 1969. Climate of the upper air, Part I. Southern Hemisphere, Vol.1, Temperatures, dew points, and heights at selected pressure levels. NAVAIR Rep. 50-1C-55, U.S. Naval Weather Serv. Command, Washington D.C., 135 pp.

Trenberth, K. E., Olson, J. G and Large, W. G. 1989. A global ocean wind stress climatology based on ECMWF analyses. NCAR/TN-338+STR, National Center for Atmos. Res., Boulder, Colorado, 93 pp.

van Ypersele, J.-P. 1989. Coupled ocean and sea-ice models: review and perspectives. In: Climate and geosciences (ed. A. Berger, S. Schneider and J. Cl. Duplessy). Kluwer Academic Publishers, Dordrecht, 253-277.

Wadhams, P., Lange, M. A. and Ackley, S. F. 1987. The ice thickness distribution across the Atlantic sector of the Antarctic Ocean in midwinter. J. Geophys. Res. 92 , 14,535-14,552.

Walin, G. 1993. On the formation of ice on deep weakly stratified water. Tellus 45A, 143-157.

Whitworth, T. III, Nowlin, W. D., Pillsbury, R. D., Moore, M. I. and Weiss, R. F. 1991. Observations of the Antarctic Circumpolar Current and deep boundary current in the southwest Atlantic. J. Geophys. Res. 96, $15,105-15,118$.

Xie, P. and Arkin, P. A. 1996. Analyses of global monthly precipitation using gauge observations, satellite estimates and numerical model predictions. J. Clim. 9, $840-858$.

Zwally, H. J., Comiso, J. C. and Gordon, A. L. 1985. Antarctic offshore leads and polynyas and oceanographic effects. In: Oceanology of the Antarctic continental shelf (ed. S. S. Jacobs). Antarctic Research Series 43, Amer. Geophys. Union, 203-226. 